\title{
Tumor-Associated Peptide Antigens Present
}

National Cancer Institute

\section{Source}

National Cancer Institute. Tumor-Associated Peptide Antigens Present. NCI Thesaurus. Code C154155.

An indication that expression of part or all of a study-specific panel of tumor-associated peptide antigens has been detected in a sample. 